\title{
ANALISIS TEKNIK DAN KUALITAS TERJEMAHAN UNGKAPAN BERMAJAS METAFORA PADA NOVEL A THOUSAND SPLENDID SUNS KARYA KHALED HOSSEINI
}

\author{
Etty Ekowati ${ }^{1}$; M. R. Nababan ${ }^{2}$; Riyadi Santosa ${ }^{2}$ \\ ${ }^{1}$ Pascasarjana Linguistik, Universitas Sebelas Maret \\ ${ }^{2}$ Universitas Sebelas Maret Surakarta. \\ 1ettyeka.solo@gmail.com
}

\begin{abstract}
This study is aimed at: (1) analyzing the translation technique used by the translator in translating nominative, predicative and sentence metaphoric expressions (2) analyzing the shift of syntactic functions and figurative language as the result of the application of the translation techniques and (3) the impact of the translation techniques towards the translation's quality of metaphoric expresssions in terms of accuracy, acceptibility and readibility.In analyzing the categories of metaphoric expressions, this study is based on Wahab theory (1995), The translation techniques which are applied in analyzing the data are based on Molina and Albir's theory(2002), and in analyzing the translation quality, this study uses translation quality assesment by Nababan et al.(2012). This method of this study is descriptive qualiative which focuses on single case study. The source of data is a document, a novel entitled 'A Thousand Spendid Suns', questionaires from the raters and respondens are also the source of data in this study. The technique of data analysis is based on Spradley 's theor. The result of analysis shows that there are 134 data of metaphoric expressions found in the novel and 13 techniques applied in translating the metaphoric expression. Related to the accuracy, acceptability and readibility, there are 104 data accurate and the rest are categorirized less accurate and innacurate. In term of acceptability, 112 data categorized acceptable and related to readibility, 130 data have high readibility. From the data obtained, Established Equivalent technique has good impact toward the accuracy of the translation while Discursive Creation technique hasn't good impact although they may have good impact in acceptability and readibility. This study also shows that there are two types of shifts, the shifts of the syntactic function and the shift of the figure of speech.
\end{abstract}

Key words: Metaphor, syntactic function, translation techniques

\section{PENDAHULUAN}

Dari karya terjemahan berbagai cabang ilmu, yang menarik untuk dikaji adalah terjemahan gaya bahasa dalam teks sastra, karena gaya bahasa dalam teks sastra lebih rumit daripada gaya bahasa dalam teks ilmiah seperti laporan penelitian atau makalah. Kerumitan gaya bahasa dalam teks sastra kadang- kadang menjadi penyebab sulitnya penerjemahan.Seperti yang dinyatakan oleh Nababan (2003: 59), “ Kompleksitas stilistik juga merupakan salah satu faktor penyebab sulitnya penerjemahan itu dilakukan" 
Mengenai pentingnya aspek gaya bahasa dalam penerjemahan dinyatakan oleh Nida dan Taber( 1982:12) bahwa penerjemahan " consists in reproducing in the receptor language the closest natural equivalent of the source language message, first in the term of meaning and secondly in terms of style". Menurut definisi ini, menerjemahkan berarti mereproduksi pesan yang ada dalam bahasa sumber kedalam bahasa sasaran dengan padanan yang wajar dan paling dekat dengan Bsu, pertama-tama sehubungan dengan arti dan kedua sehubungan dengan gaya.

Penulis karya sastra, termasuk novel seringkali menggunakan gaya tertentu untuk memperkaya makna sehingga dapat menyampaikan pesan yang diinginkan secara lebih leluasa (Masduki, 2011:41). Gaya bahasa yang sering digunakan dalam novel diantaranya adalah penggunaan bahasa kias atau majas.

Bahasa kias atau majas merupakan gaya penulis dalam usahanya supaya memberikan efek tertentu pada pembacanya. Eka Murtisari dalam bukunya menyatakan bahwa majas atau bahasa kias adalah "penyimpangan dari pemakaian bahasa yang biasa, yang makna kata atau rangkaian katanya digunakan untuk menghidupkan atau meningkatkan efek dan menimbulkan konotasi tertentu” (2012: 27).

Dengan demikian penulis karya sastra yang menggunakan bahasa kias pasti berharap bahwa tulisannya akan menjadi lebih hidup, lebih memberikan efek tertentu dan dimaknai dengan konotasi tertentu oleh para pembacanya oleh karena itu dalam penerjemahan seorang penerjemah sedapat mungkin berusaha untuk dapat mempertahankan makna dan gaya teks bahasa sumber agar amanat dari teks bahasa sumber tersampaikan dengan baik sesuai dengan keinginan penulis.

Harapan seperti itulah yang sering menjadi tantangan penerjemah dalam menerjemahkan karya-karya sastra karena suatu kata kias atau ungkapan bermajas tidak selalu dapat diterjemahkan sesuai dengan makna kata yang membentuknya apalagi ungkapan bermajas yang digunakan juga seringkali berbeda karena perbedaan budaya.Seperti yang dinyatakan oleh Nababan, "karena budaya bahasa sumber dan bahasa sasaran berbeda satu sama lain, gaya bahasa yang digunakan oleh kedua bahasa itu tentu saja berbeda" (2003:59).

Di Indonesia, sudah banyak terjemahan karya sastra yang beredar terutama novel yang berbahasa Inggris dan salah satunya adalah novel yang berjudul " $A$ Thousand of Splendid Suns karya khaleed Hosseini”. Novel ini merupakan salah satu 
novel terlaris didunia (International Best Seller) dan mendapatkan banyak pujian yang salah satunya adalah dari Los Angeles Times, yang menyatakan, "What keeps this novel vivid and compelling is Hosseini's eye for the textures of daily life and his ability to portray a full range of human emotions"'(2007)

Kata kias yang berupa majas metafora banyak digunakan dalam novel ini, oleh karena itu pada tulisan ini penulis akan mengkaji teknik penerjemahan yang diterapkan pada metafora nominatif, predikatif dan kalimatif pada majas metafora dalam novel $A$ Thousand splendid Suns, ada tidaknya pergeseran fungsi sintaksis dari Bsu ke dalam Bsa, ada tidaknya pengaruh pergeseran tersebut terhadap pergeseran majas serta pengaruh penerapan teknik dan pergeseran majas tersebut terhadap kualitas terjemahan berdasar pada keakuratan, keberterimaan dan keterbacaan. Penelitian ini bertujuan mendeskripsikan: jenis teknik penerjemahan yang diterapkan pada metafora nominatif, predikatif dan kalimatif dalam novel "A Thousand Splendid Suns"; ada tidaknya pergeseran fungsi unsur sintaksis, pergeseran majas metafora ke majas lain atau tidak bermajas sebagai sebagai akibat diterapkannya teknik-teknik penerjemahan; dan mendeskripsikan kualitas terjemahan novel “A Thousand Splendid Suns"dari aspek keakuratan, keberterimaan dan keterbacaan.

\section{TEORI DAN METODOLOGI}

Penelitian ini adalah penelitian penerjemahan yang berorientasi pada produk dengan pendekatan kualitatif deskriptif. Penggunaan beberapa data berupa angka dalam penelitian ini hanyalah sebagai alat mempermudah pengumpulan dan analisis data. Bersifat deskriptif karena mendeskripsikan teknik-teknik penerjemahan yang digunakan dalam ungkapan bermajas metafora dalam novel A Thousand Splendid Suns karya Khaled Hosseini, serta mengkaji pengaruh teknik - teknik tersebut terhadap kualitas terjemahan. Penelitian ini bersifat kualitatif karena data yang dikumpulkan berupa kata, frase atau kalimat yang menggunakan majas metafora. Hal ini seperti yang dinyatakan oleh Bodgar dan Taylor yang dikutip oleh Lexy J Moleong (2006:4) bahwa penelitian kualitatif adalah prosedur penelitian yang menghasilkan karya ilmiah dengan menggunakan atau meneliti data deskriptif berupa kata-kata tertulis atau lisan dari orang- orang atau perilaku yang dapat diamati terhadap status kelompok manusia, suatu objek atau sutu kelompok kebudayaan. Data tersebut kemudian dianalisis dan 
diinterpretasi untuk ditarik simpulannya. Dalam penelitian ini data yang dikumpulkan adalah terjemahan kata, kelompok kata atau kalimat yang bermajas metafora pada novel A Thousand Splendid Suns.

Penelitian ini juga bersifat studi kasus tunggal dengan sasaran atau objek produk penerjemahan metafora berdasarkan fungsi sintaksisnya dalam novel ATSS. Penelitian ini juga merupakan penelitian etnografis terkait dengan adanya kegiatan pengumpulan data ke lapangan, yaitu penyebaran kuesioner serta wawancara untuk memperoleh data tentang kualitas terjemahan

Dalam penelitian ini digunakan dua jenis data dan sumber data primer, yaitu: (1) metafora dan terjemahannya yang terdapat di Novel ATSS dan (2) tingkat keakuratan dan keberterimaan terjemahan metafora yang bersumber dari rater dan informan. Untuk pengambilan data diterapkan teknik sampling bertujuan (purposive sampling). Dan untuk pengumpulan data, teknik yang digunakan adalah: (1) teknik observasi: untuk memperoleh data metafora; dan (2) kuesioner: untuk mendapatkan data tentang tingkat keakuratan dan keberterimaan terjemahan metafora.

\section{HASIL DAN PEMBAHASAN}

1.Metafora berdasarkan fungsi sintaksisnya

Hasil penelitian merupakan hasil analisis tentang ungkapan metafora dalam domain struktur teks yang ada di dalam novel "A Thousand Splendid Suns" yang berwujud kata, frasa maupun kalimat yang mempunyai fungsi sintaksis sebagai nominatif, predikatif dan kalimatif. Hasil temuan yang berupa ungkapan metafora pada novel "A Thousand Splendid Suns" kemudian diklasifikasikan berdasarkan teori Wahab (1995: 72). Dari hasil analisis peneliti, ditemukan metafora Nominatif sebanyak 47 data atau 35,07\% dengan rincian pada tahap orientasi 16 data atau 11,94\%, tahap konflik 26 data atau 19,40\% dan tahap penyelesaian sebanyak 5 data atau 3, $73 \%$, metafora Predikatif sebanyak 76 atau 56,71\% data dengan rincian, pada tahap orientasi 40 data atau 29,85\%, tahap konflik 32 data atau 23,88\%, tahap penyelesaian 5 data atau $3,73 \%$ dan metafora kalimatif sebanyak 10 data atau 7,46\% dengan rincian tahap orientasi 5 data atau 3,73\%, tahap konflik 4 atau data atau 2,98\% dan tahap penyelesaian 1 data atau $0,74 \%$. 


\section{. a. Metafora nominatif}

Metafora nominatif adalah metafora yang muncul sebagai nomina kalimat. Metafora nominatif ini kemudian dibagi lagi menjadi dua yaitu metafora nominatif subjektif atau disebut dengan metafora nominatif saja dan metafora nominatif objektif yang lazim disebut dengan metafora komplementatif. Pada metafora nominatif, metafora muncul pada subjek kalimat. Contoh :

Kode data : 114/ATSSE/345 dan 114/ATSSI/435

$\mathrm{BSu} \quad$ : Bile surged up her chest

Bsa : Rasa pahit memancar dari dadanya.

Menurut 'Dictionary of Contemporsry English", Bile adalah, a bitter, yellow or greenish liquid secreted by the liver, that aids in absorbtion and digestion of fat. Dalam ungkapan ini yang digunakan sebagai persamaan adalah kata bitter yang berarti pahit. Didalam cerita, rasa pahit dirasakan laila ketika semuanya harus berakhir secara mengenaskan. Suaminya, Rasheed harus mati secara tragis karena perkelahian antara Rasheed dengan dia sendiri dan Mariam. Dalam kalimat tersebut kata bile merupakan metafora nominatif yang berfungsi sebagai subjek kalimat.

b.Metafora predikatif adalah metafora yang muncul dalam predikat kalimat saja sedangkan bagian lain yaitu subjek dan komponen lain jika ada dinyatakan dalam makna langsung.

\section{Contoh :}

Kode data : 030/ATSSE/109 dan 030/ATSSI/139

$\mathrm{BSu}$ : ..his glasses perched on the tip of his nose.

Bsa : ... kacamatanya bertengger di ujung hidungnya.

Kata perched atau bertengger biasa digunakan untuk unggas misalkan burung atau ayam yang hinggap di suatu tempat yang lebih tinggi. Namun di dalam cerita ini kata perched atau bertengger digunakan untuk benda mati yaitu kacamata yang diletakkan di ujung hidung. Kata perched dalam klausa ini merupakan verba dari klausa, oleh karena itu metafora dalam klausa ini adalah metafora predikatif. 
c. Metafora kalimatif

Metafora kalimatif adalah metafora atau lambang kias yang tidak hanya muncul pada subjek atau predikatnya saja, tetapi pada seluruh komponen kalimat.

\section{Contoh :}

Kode data : 013/ATSSE/43 dan 013/ATSSI/63

$\mathrm{BSu}$ : The seeds for what she did was planted long ago $\mathrm{BSa}$ : Bibit dari apa yang dia lakukan tertanam sejak lama

Keseluruhan kalimat di atas merupakan ungkapan metaforis karena ungkapan tersebut tidak merujuk ke arti sebenarnya seperti yang ada dalam Bsa. Bibit yang ditanam yang dimaksud di dalam kalimat tersebut adalah perbuatan yang dilakukan sebelumnya.

2. Temuan teknik penerjemahan dalam terjemahan novel A Thousand Splendid Suns.

Dalam terjemahan novel ATSS ini, dari 134 data ditemukan penggunaan 13 teknik penerjemahan yaitu, Padanan lazim, Kreasi Diskursif, Harfiah, Modulasi, Eksplisitasi atau Amplifikasi, generalisasi, penghilangan (deletion), Transposisi, Peminjaman murni,variasi, reduksi dan partikularisasi. Penerapan teknik- teknik tersebut memiliki frekuensi kemunculan yang berbeda -beda . Rinciannya adalah, teknik Padanan Lazim sebanyak 79 kali, Kreasi Diskursif sebanyak 116 kali, Harfiah sebanyak 6 kali, Modulasi sebanyak 12 kali , eksplisitasi/amplifikasi sebanyak 11 kali, Generalisasi sebanyak 5 kali, penghilangan (deletion) sebanyak 3 kali, Transposisi 3 kali, peminjaman murni 4 kali partikularisasi 1 kali, addition ( penambahan 2 kali, reduksi 2 kali dan variasi 3 kali. Dari penerapan teknik penerjemahan tersebut, terdapat 20 ungkapan metafor dengan penerapan lebih dari satu teknik. Temuan penerapan teknik penerjemahan ungkapan metafora dalam novel A Thousand Splendid Suns:

a. Teknik penerjemahan Padanan Lazim

Teknik penerjemahan Padanan Lazim adalah menerjemahkan dengan menggunakan padanan yang telah dikenal atau yang ada di dalam kamus atau menggunakan istilah yang sudah lazim digunakan dalam bahasa sasaran. 
Kode data : 114/ATSSE/345 dan 114/ATSSI/435

$\mathrm{BSu} \quad$ : Bile surged up her chest

Bsa : Rasa pahit memancar dari dadanya.

Menurut 'Dictionary of Contemporsry English", Bile adalah, a bitter, yellow or greenish liquid secreted by the liver, that aids in absorbtion and digestion of fat. Dalam ungkapan ini yang digunakan sebagai persamaan adalah kata bitter yang berarti pahit. Didalam cerita, rasa pahit dirasakan laila ketika semuanya harus berakhir secara mengenaskan. Suaminya, Rasheed harus mati secara tragis karena perkelahian antara Rasheed dengan dia sendiri dan Mariam. Dalam kalimat tersebut kata bile merupakan metafora nominatif yang berfungsi sebagai subjek kalimat.

\section{b. Teknik Penerjemahan Kreasi Diskursif}

Teknik penerjemahan ini merupakan teknik yang menggunakan padanan sementara yang tak terduga dan keluar dari konteks dengan maksud menarik pembaca teks terjemahan.

\section{Contoh 1}

Kode data : 005/ATSSE/17 dan 005/ATSSI/32

Bsu : Since then, thought of classroom and teachers had rattled around Mariam's head.

Bsa : Sejak saat itu, pikiran Mariam tentang ruang kelas dan guru-guru bermain-main di dalam kepala Mariam.

Terjemahan kata rattled around menjadi bermain-main merupakan terjemahan sementara yang keluar dari konteks. Rattled around yang mempunyai arti tinggal atau mendiami yang kemudian diterjemahkan dengan kata bermain- main menjadikan terjemahannya menjadi tidak sepadan dan keluar konteks.

c. Teknik penerjemahan Harfiah

Merupakan teknik penerjemahan dengan menerjemahkan secara harfiah suatu kata dalam bahasa sumber, namun penerjemah telah menyesuaikan struktur kalimat terjemahan dengan struktur kalimat yang berlaku dalam bahasa sasaran.

Contoh :

Kode data : 013/ATSSE/43 dan 013/ATSSI/63

$\mathrm{BSu}$ : The seeds for what she did was planted long ago

$\mathrm{BSa}$ : Bibit dari apa yang dia lakukan tertanam sejak lama 
Penerjemah menerjemahkan kata kata yang ada sesuai dengan aslinya namun penerjemah juga menyesuaikan struktur kalimat yang berlakudalam bahasa sasaran, seperti kata was planted yang merupakan ungkapan dalam bentuk pasif dalam bahasa sumber diterjemahkan dalam bentuk pasif dalam bahasa sasaran dengan menggunakan awalan ter sehingga menjadi tertanam.

d.Teknik penerjemahan modulasi

Teknik ini digunakan karena ada perbedaan sudut pandang antara BSu dan Bsa, sehingga dalam terjemahan terjadi perubahan sudut pandang dari Bsu ke Bsa.Modulasi adalah teknik yang digunakan dengan mengubah sudut pandang, fokus atau kategori kognitif kaitannya dengan teks dari bahasa sumber.

Contoh :

Kode data : 008/ATSSE/21 dan 008/ATSSI/36

$\mathrm{BSu}$ : But she could believed that she could land safely into her father's clean manicured hands

BSa : Tetapi Mariam yakin Jalil tidak akan pernah membiarkannya jatuh Pada contoh di atas frasa land safely diterjemahkan menjadi tidak akan membiarkannya jatuh. Dalam terjemahan terjadi perbedaan focus dari she yang dalam BSu merupakan Subyek kalimat menjadi Jalil yang tadinya merupakan pelengkap dalam kalimat BSu.

e. Teknik penerjemahan amplifikasi (Eksplisitasi)

Teknik amplifikasi digunakan dengan memberi keterangan secara eksplisit agar pesan dalam Bsu tersampaikan kepada pembaca teks BSa sesuai dengan pesan yang ada dalam BSu.

\section{Contoh 1}

Kode data : 102/ATSSE/289 dan 102/ATSSI/363

$\mathrm{BSu}$ : Laila walked away feeling stung

BSa : Laila menyingkir merasa terluka.

Pada terjemahan di atas kata stung diterjemahkan dengan kata terluka agar pesan penulis kepada pembaca novel ini tersampaikan dengan baik walaupun dengan diterjemahkan demikian kalimat yang tadinya bermajas menjadi tidak bermajas. 
f. Teknik penerjemahan generalisasi

Teknik generalisasi digunakan jika padanan yang spesifik dalam Bsa tidak ditemukan, sehingga penerjemah menggunakan kata yang lebih umum.

Contoh

Kode data : 065/ATSSE/201 dan 065 /ATSSI/253

$\mathrm{BSu}$ : She sent the tendrils of her mind out of the room, out of the window,

BSa : Dia mengirimkan pikirannya keluar dari ruangan ini, keluar dari jendela, menjauhi Abdul Sharif, melayang di jalanan, di atas rumah rumah beratap

g. Deletion (penghilangan)

\section{Contoh 1}

Kode data : 099/ATSSE/ ATSSE/ 287 dan 099/ATSSI/361

$\mathrm{BSu}$ : Laila loved the moist kisess Zalmai planted on her cheeck

BSa : Laila menyukai ciuman basah Zalmai di pipinya.

Pada contoh di atas kata planted tidak diterjemahkan atau dihilangkan di dalam bahasa sasaran sehingga terjemahan untuk kata planted tidak ada dalam bahasa sasaran.

h. Teknik penerjemahan Transposisi

Teknik ini digunakan dengan mengubah susunan kata (struktural adjustment) atau menggeser (shifting) kategori kata. Apabila struktur kata dalam bahasa sumber berbeda dengan bahasa sasaran perubahan susunan kata( structural adjustment) wajib dilakukan. Sementara pergeseran kategori yang dimaksud adalah perubahan kelas kata dari bahasa sumber ke bahasa sasaran.

Contoh

Kode data : 071/ATSSE/216 dan 071/ATSSI/271

$\mathrm{BSu}$ : Mariam was 33 years old now, but the word harami still had sting

BSa : Sekarang Mariam berumur 33 th, namun kata harami masih menyengatnya.

Dalam BSu ada kata sting yang merupakan kata benda atau noun yang berfungsi sebagai objek dari klausa dalam kalimat namun terjemahan dalam BSa untuk kata tersebut adalah menyengat yang merupakan kata kerja dan berfunsi sebagai predikat klausa dalam kalimat tersebut. Jadi dalam kalimat ini ungkapan metafor sting 
yang merupakan kata benda atau noun berubah kelas katanya menjadi kata kerja atau verba.

i. Teknik Penerjemahan Peminjaman murni

Teknik ini digunakan dengan meminjam kata atau ungkapan yang ada dalam $\mathrm{BSu}$.

Contoh :

Kode data : 120/ATSSE/350 dan 120/ATSSI/442

$\mathrm{BSu}$ : Tell her she is the sultan of my heart

BSa : katakan kepadanya bahwa dia adalah sultan di hatiku.

Kata sultan di dalam BSu tidak diterjemahkan ke dalam bahasa sumber namun tetap seperti yang ada di dalam BSu tanpa ada penyesuaian ejaan.

j. Teknik variasi.

Dalam terjemahan ungkapan metafor pada novel ini penerapan teknik variasi terdapat pada:

Kode data : 001/ATSSE/4 dan 001/ATSSI/16

$\mathrm{BSu}$ : Jalil said he was his little flower

BSa : Menurut jalil dia adalah bunga mungilnya

Penerapan teknik variasi digunakan dalam menterjemahkan kata his dalam BSu menjadi nya dalam BSa.

k. Teknik penambahan (Addition)

Kode data : 095/ATSSE/263 dan 095/ATSSI/331

Bsu : The room turn into a pressure cooker

Bsa : Kamar itu seolah olah menjadi tungku pemanas

Penambahan kata seolah- olah dalam Bsa merupakan penerapan teknnik addition.

L. Teknik Partikularisasi

Teknik partikularisasi adalah teknik yang menggunakan istilah yang lebih khusus atau spesifik.

Contoh :

Kode data : 019/ATSSE/63

$\mathrm{BSu}:$....only then would the metal fist grippping her belly let go. 
BSa : ....Hanya setelah cengkeraman tangan besi melepas perutnya

Penerapan teknik partikularisasi ada pada penerjemahan kata metal yang dalam terjemahannya menjadi besi yang merupakan salah satu jenis metal atau logam.

3. Temuan pergeseran fungsi dan majas dalam penerjemahan ungkapan metafora dalam novel A Thousand spendid Suns.

a. Pergeseran fungsi

Hanya ada 4 data yang terjemahannya mengalami perubahan fungsi yang dapat dilihat pada :

Kode data : 023/ATSSE/91 - 023/ATSSE/ 119

$\mathrm{BSu}$ : Mariam was dumbfounded that she could miss in such a crippling manner a being she had never seen before.

BSa : Mariam tersekiap ketika menyadari betapa kerinduan terhadap mahkluk yang bahkan belum pernah dia lihat dapat mencekamnya sedemikian rupa.

Dalam contoh terjemahan di atas kata crippling merupakan ungkapan metafor karena digunakan untuk memberi keterangan pada kata miss. Frase in such a crippling manner yang merupakan frase benda yang merupakan metafor nominatif berubah menjadi mencekamnya sedemikian rupa yang merupakan metafora predikatif. Dengan demikian pada contoh di atas ada pergeseran fungsi.

Kode data : 074 / ATSSE/216 dan 074/ATSSI/271

$\mathrm{BSu}$ : Mariam was 33 years old now but the word harami still had sting

BSa: Sekarang Mariam berumur 33 tahun namun kata harami masih menyengatnya

Kata sting adalah kata benda dengan fungsi sebagai objek yang diterjemahkan menjadi menyengatnya yang merupakan kata kerja dengan fungsi sebagai predikat. Dengan demikian ada pergeseran fungsi sintaksis dari kata tersebut dari nominatif menjadi predikatif.

\section{b. Pergeseran Majas}

Untuk pergeseran majas, ada 2 macam yaitu : pertama, dari Bsu yang menggunakan majas Metafora ke Bsa yang tidak menggunakan majas sebanyak 20 data dan yang kedua dari Bsu yang menggunakan majas metafora ke majas Simile sebanyak 4 data. Pergeseran majas dapat dapat dilihat pada data : 
b.1 Pergeseran dari majas metafora menjadi tidak bermajas

Contoh :

Kode data : 008/ATSSE/21 dan 008/ATSSI/36 kreasi diskursif

$\mathrm{BSu}$ : But she she believe could land safely into her father's clean manicured hands

BSa : Tetapi Mariam yakin Jalil tidak akan membiarkannya jatuh

Ungkapan land safely merupakan majas metafor karena kata land safely yang

biasanya untuk pesawat ketika mendarat, pada ungkapan ini digunakan untuk manusia.

b2. Pergeseran dari majas metafora ke majas Simile.Dalam terjemahan novel A Thousand Splendid Suns terdapat 3 data majas metafora dalam BSu yang bergeser menjadi majas Simile dalam BSa. Hal ini dapat dilihat pada data :

Kode data : 084/ATSSE/234 dan 084/ATSSI/294

$\mathrm{BSu}$ : It was the fear of the goat, released in the tiger's cage, when the tiger looked up from its paws, begin to growl.

BSa : Mariam ketakutan bagaikan seekor kambing yang dimasukkan kedalam kerangkeng harimau, ketika sang harimau mengangkat cakarnya dan menggeram

4. Kualitas terjemahan novel A Thousand splendid Suns.

Untuk menilai kualitas terjemahan dari novel ini peneliti bersama-sama dengan para rater melakukan penilaian kualitas terjemahan dari ketiga aspek tersebut. Peneliti memberikan kuesioner kepada masing- masing rater untuk menilai kualitas terjemahan. Masing-masing rater akan menilai kualitas terjemahan novel dari aspek keakuratan, keberterimaan dan keterbacaan berdasarkan parameter yang telah ditentukan. Dari hasil penilaian masing-masing rater diperoleh kesepakatan mengenai tingkat keakuratan, keberterimaan dan keterbacaan terjemahan novel A Thousand Spendid Suns. Untuk menentukan kualitas terjemaha dalam novel ini digunakan parameter kualitas penerjemahan oleh Nababan, dkk.

a. Tingkat Keakuratan terjemahan .

Hasil penelitian terjemahan novel A Thousand Spendid Suns menunjukkan bahwa dari 134 data yang ada, terdapat 104 data atau sekitar 77,61\% merupakan terjemahan akurat, kurang akurat sebanyak 5,97\% dan tidak akurat sebanyak 16, $41 \%$. Untuk jelasnya bisa dilihat pada tabel berikut. 
Tabel.1Tingkat keakuratan terjemahan ungkapan "Metafora dalam A Thousand Spendid Suns"

\begin{tabular}{|l|l|l|l|}
\hline No & Tingkat Keakuratan & jumlah & Prosentase \\
\hline 1 & Akurat & 104 & $77,61 \%$ \\
\hline 2 & Kurang akurat & 8 & $5,97 \%$ \\
\hline 3 & Tidak akurat & 22 & $16,41 \%$ \\
\hline & Jumlah & 134 & $100 \%$ \\
\hline
\end{tabular}

b. Keberterimaan terjemahan

Dalam terjemahan novel ini ditemukan terjemahan berterima sebanyak 112 atau $83,60 \%$, kurang berterima sebanyak 13 data atau 9, 70\% dan kategori tidak berterima sebanyak 9 data atau 7,0\%. Untuk lebih jelasnya dapat dilihat pada tabel berikut ini :

Tabel. 2 Tingkat Keberterimaan terjemahan "A Thousand Splendid Suns"

\begin{tabular}{|l|l|l|l|}
\hline No & Tingkat Keberterimaan & Jumlah & Prosentase \\
\hline 1 & Berterima & 112 & $83,60 \%$ \\
\hline 2 & Kurang berterima & 13 & $9,70 \%$ \\
\hline 3 & Tidak berterima & 9 & $7,0 \%$ \\
\hline & jumlah & 134 & $100 \%$ \\
\hline
\end{tabular}

c. Tingkat keterbacaan terjemahan

Dalam terjemahan novel yang diteliti ini terdapat terjemahan dengan tingkat keterbacaan tinggi sebanyak 130 data atau 97,01\%, dengan tingkat keterbacaan sedang 1 data atau $0,74 \%$ dan terjemahan dengan keterbacaan rendah sebanyak 3 data atau $2,23 \%$.

\section{SIMPULAN}

Berdasarkan uraian di atas dapat disimpulkan sebagai berikut:

1.Dalam menterjemahkan ungkapan bermajas metafora pada novel $A$ Thousand Splendid Suns, diterapkan 13 teknik penerjemahan yaitu, teknik Padanan lazim, Kreasi Diskursif, Harfiah, Amplifikasi, Transposisi, Modulasi, Generalisasi, Deletion (penghilangan), Partikularisasi, Reduksi, Peminjaman Murni, penambahan (Addition) dan Variasi. Penerapan teknik Padanan Lazim paling dominan diantara teknik-teknik yang lain dan teknik tersebut banyak diterapkan pada metafora predikatif. Penerapan teknik padanan lazim banyak menghasilkan kualitas terjemahan yang baik. Sedangkan 
penerapan teknik penerjemahan diskursif banyak menghasilkan terjemahan yang kurang atau tidak akurat.

2.Penerapan teknik kreasi diskursif, transposisi dan amplifikasi memungkinkan terjadinya pergeseran kategori kata dalam fungsi sintaksis atau kategori fungsi sintaksis.

3. Ada pergeseran terjemahan dari majas metafora pada BSu menjadi majas simile pada Bsa dan dari majas metafora pada BSu menjadi tidak bermajas pada BSa.

4.Sebagian besar ungkapan bermajas metafora diterjemahkan secara akurat, berterima dan mempunyai keterbacaan tinggi, namun demikian masih ada terjemahan yang kurang dan tidak akurat maupun berterima serta mempunyai keterbacaan sedang maupun rendah. Secara keseluruhan berdasarkan nilai reratanya terjemahan novel $A$ Thousand Splendid Suns karya Khaled Hosseini yang diterjemahkan oleh Berliani M. Nugrahani termasuk kategori baik. Berdasarkan apa yang disimpulkan di atas, hal -hal yang perlu diperhatikan oleh penerjemah dan peneliti selanjutnya adalah:

1. Bagi penerjemah

Bagi penerjemah novel khususnya novel yang ditulis oleh pengarang dengan latar belakang ilmu non sastra seperi khaleed Hosseini, yang harus diperhatikan adalah jika menerjemahkan ungkapan kias dengan menggunakan teknik kreasi diskursif. Khaleed Hosseini yang berlatar belakang seorang dokter kadangkadang menggunakan istilah- istilah ilmu kedokteran atau ilmu biologi yang kurang dipahami oleh mayarakat pada umumnya, sehingga penerjemah harus menggunakan teknik yang tepat sehingga tidak ada distorsi makna dalam terjemahan.

2. Bagi peneliti selanjutnya.

Penelitian tentang gaya bahasa yang digunakan dalam novel A Thousand splendid Suns masih banyak yang bisa dikaji karena khaleed Hosseini memiliki gaya yang khas dalam tulisannya; penggunaan istilah atau ungkapan metafora khas yang mungkin belum dipakai orang lain ditemukan dalam novel ini sehingga masalah -masalah dalam menterjemahkan ungkapan-ungkapan khasnya akan merupakan hal yang menarik untuk dikaji bagi peneliti selanjutnya. 


\section{DAFTAR PUSTAKA}

Masduki. (2011). Kesepadanan makna dan gaya di dalam novel The Highest Tide dan terjemahannya. Desertasi. Surakarta. Universitas Sebelas Maret.

Moleong, L. (2010). Metode penelitian kualitatif(Edisi Revisi). Bandung: Remaja Rosda Karya.

Nababan, M.R. (2003). Teori menerjemah bahasa Inggris.Yogyakarta: Pustaka Pelajar

Nababan, M.R. (2004). Strategi penilaian kualitas terjemahan dalam Jurnal Linguistik Bahasa (JLB), Volume 2, hal 54.

Nababan, M.R. et al. (2012). Pengembangan model kualitas terjemahan dalam Kajian Linguistik dan Sastra, Vol.24, no1 hal 39-57.

Mark, P.N. (1988). Textbook of translation. Shanghai: Foreign Language Education Press.

Nida \& Taber. (1982). The theory and practice of translation. Leiden: E.J.Brill.

O’Grady, W. et al. (1997). Contemporary linguistics: an introduction. London: Longman.

Santosa, R. (2003). Semiotika sosial. Surabaya: Pustaka Eureka dan Jp Press.

Silalahi, R. (2009). Dampak teknik, metode dan ideologi penerjemahan pada kualitas terjemahan teks Medical Surgical Nursing dalam Bahasa Indinesia. Disertasi. Medan. Universitas Sumatera Utara.

Tim Penyusun Kamus Pusat Bahasa,2001. Kamus Besar Bahasa Indonesia, Jakarta: Balai Pustaka. 